\title{
A EXPERIÊNCIA DO LEILÃO ELETRÔNICO NO BRASIL: REFLEXÕES POSSÍVEIS FRENTE AO NOVO CORONAVÍRUS
}

\author{
Romulo Sérgio de Carvalho Guerra ${ }^{1}$
}

\section{Resumo:}

Este estudo tem por objetivo discutir o leilão eletrônico e suas contribuições ante o isolamento social imposto pelo novo coronavírus. Pensado nesse reflexo social, percebeu-se alternativas viáveis à comunidade jurídica tendo por base o leilão eletrônico, cujo alcance e resolutividade supera o leilão presencial. No leilão eletrônico o patrimônio dos executados é protegido de depreciação financeira, garante-se o princípio da celeridade processual e mostra-se como importante ferramenta no isolamento social. Constitui uma forma segura de expropriação judicial com transparência, rapidez na almoeda de bens e maior arrecadação financeira. A pesquisa possui abordagem qualitativa, método exploratório e revisão bibliográfica.

Palavras-chave: Leilão virtual, Processo de execução, Internet, COVID-19, Isolamento Social.

\section{THE EXPERIENCE OF ELECTRONIC AUCTION IN BRAZIL: POSSIBLE REFLECTIONS AGAINST THE NEW CORONAVIRUS}

\begin{abstract}
:
This study aims to discuss the electronic auction and its contributions to the social isolation imposed by the new coronavirus. Considering this social reflex, realized viable alternatives to the legal community based on the electronic auction, whose scope and resolvability surpasses the in-person auction. The Electronic Auction protects the assets of executed financial depreciation, guarantees the principle of procedural speed and is an important tool in social isolation. It is a safe form of judicial expropriation with transparency, speed in the disposal of assets and greater financial collection. The research has a qualitative approach, exploratory method and bibliographic review.
\end{abstract}

Keywords: Virtual auction, Execution procedure, Internet, COVID-19, Social isolation.

\section{INTRODUÇÃO}

O presente artigo tem como objetivo discutir o leilão eletrônico, suas características e contribuições jurídicas em tempos de isolamento social imposto pelo novo coronavírus. A Convide-19, doença causada pelo coronavírus que foi declarada como pandemia pela

\footnotetext{
${ }^{1}$ Doutorando em Direito e Segurança na NOVA School of Law, Lisboa Portugal. Estudou: Mestrado em Direito na Faculdade de Direito de Lisboa, especialização - Pós Graduação em Direito Civil e Prática Jurídica pela Faculdade de Direito da Universidade de Lisboa - Portugal, Graduação em Direito pela Universidade Veiga de Almeida, Rio de Janeiro, Brasil. Atualmente é Advogado. Assistente de Leiloeiro de 2001 até 2005. Leiloeiro Público Oficial de 2005 até 2018.
} 
Organização Mundial da Saúde no ano de 2020. Vários países no mundo, dentre eles o Brasil, vêm identificando pessoas contaminadas e mortas por esta enfermidade.

Uma das medias para conter a disseminação do vírus é o isolamento social que trouxe impactos econômicos, nas relações de consumo, cíveis, educacionais, familiares e penais. Assim, neste momento, é necessário pensar nos impactos jurídicos trazidos pelo novo coronavírus e sua relação com institutos e princípios utilizados no Direito Brasileiro.

Como se sabe, o Leilão judicial é um instituto jurídico que consiste na possibilidade de venda de bens móveis ou imóveis para arrecadar valores em favor de seus respectivos credores em face dos proprietários dos bens que figuram como devedores. A regra do mercado é a de maior lance possível, sendo, também, definida como a modalidade mais eficaz que permite a um particular, terceiro na demanda chamado de arrematante, apresentar lances na venda destes bens em consequência da expropriação judicial visando, sobretudo que lhe proporcione lucros. Nenhum indivíduo pode ser favorecido nos Leilões tendo privilégios na recepção de seus lances, impedindo que outros interessados participem em igualdade de condições na apresentação dos lances e consequente aquisição dos bens ofertados.

A Lei Processual Civil de 2015 baseada nos princípios do Direito Administrativo absorveu a regra do Pregão Eletrônico que visa dar maior alcance aos interessados nos leilões realizados pela Administração Pública, garantindo celeridade na efetivação dos negócios para o Estado, sobretudo, garantindo o regular cumprimento do Princípio do Devido processo Legal e da transparência.

Dentre algumas definições, em suma, o Pregão eletrônico é uma modalidade licitatória utilizada pelo governo brasileiro para contratar bens e serviços. Foi criada através da lei federal 10.520/2002 (Lei do Pregão) e regulamentado na forma eletrônica pelo decreto 4.450/2005. A mesma lei também criou o chamado "pregão presencial", que obrigava os interessados a comparecerem à negociação, liderada por um pregoeiro devidamente designado pelo órgão da administração pública licitante.

O pregão eletrônico visa, basicamente, aumentar a quantidade de participantes e baratear o processo licitatório. Permite a ampliação da disputa licitatória, com a participação de maior número de empresas de diversos estados, já que é dispensada a presença dos arrematantes concorrentes.

Com o advento do pregão eletrônico através da popularização do acesso à Internet, disponível a um número cada dia maior de pessoas nas palmas de suas mãos, foi que surgiu o 
leilão eletrônico cujo tema é de inegável importância, pois permite maior alcance e, sobretudo maior arrecadação para a satisfação nos processos, seja nas ações de execução, nas varas de famílias, nos inventários, nas reclamações trabalhistas e falências, visto que as informações se propagam com maior velocidade na rede quando comparadas com o ato do leilão judicial presencial.

Assim, considerou-se como hipótese principal deste estudo os benefícios alcançados na modalidade do leilão judicial virtual, que também podem ser alcançados em outras áreas do direito e que se analisados os erros e acertos da implementação desta modalidade haverá ganhos consideráveis, seja no aspecto da economia processual, financeiro, e sobre tudo, na preservação de vidas humanas caso seja necessário adoções extremas de quarentena até o chamado lockdown.

A pesquisa possui abordagem de natureza qualitativa, a partir do método exploratório, na busca de dados elementares acerca de um fenômeno recente nas pesquisas acadêmicas. $\mathrm{O}$ procedimento adotado foi a revisão bibliográfica sobre as características, princípios, aspectos legais inovações trazidas pela instituição do leilão judicia virtual no Brasil, também chamado leilão eletrônico.

O desenvolvimento do estudo inicia-se com uma abordagem do leilão eletrônico, seus fundamentos e princípios. O tema interfere na maneira de lidar e vender o patrimônio de uma pessoa física ou jurídica que sofre constrição judicial e mostra-se importante em tempos de isolamento social imposto pelo COVID-19 que frisa-se, foi "relatado pela primeira vez em Wuhan, China, em 31 de dezembro de 2019" (WHO, 2020) e desde então a vida de milhões de pessoas tem sido alguma forma afetada.

O Poder Judiciário, os jurisdicionados e toda a sociedade devem buscar alternativas viáveis juridicamente para que se satisfaçam os interesses das partes nas inúmeras ações judicias que estão ou estiveram paralisadas em virtude desta pandemia. E como se verá, o leilão judicial eletrônico tem se mostrado um mecanismo de grande abrangência para o ato da almoeda com alcance muito superior ao ato do leilão presencial, destacando-se como um exemplo viável que poderá ser aplicado para outros seguimentos do direito durante e após o término da referida pandemia.

\section{O LEILÃO ELETRÔNICO NO BRASIL E A PANDEMIA DE CONVID-19}

O leilão é um instituto jurídico fruto de grande repercussão no direito brasileiro. 
Podemos exemplificar que o leilão é aplicado por exemplo aos jurisdicionados que tenham ajuizado ação e que após longo litígio judicial buscou por todos os meios legais receber valores fruto de uma cobrança em um determinado caso concreto em face de uma pessoa(física ou jurídica) que em um determinado momento lhe causou prejuízos financeiros, não tendo alternativa senão buscar o ressarcimento de seu crédito em uma ação que resultou na ordem judicial da penhora, avaliação, nomeação do leiloeiro pelo Juízo e a venda do bem penhorado via Leilão Judicial para efetivamente permitir a quitação dos créditos objetos de cobrança.

O leiloeiro público nomeado pelo Juízo deverá ser um particular, registrado na Junta Comercial da sua região de atuação, que está investido de função pública delegada pelo poder Judiciário e que desempenha nos autos de um processo função similar aos antigos servidores da justiça chamados Porteiro do Auditório (RODRIGUES, 2000).

O procedimento final do leilão virtual realizado pelo leiloeiro público envolve conflito entre direitos previstos pela Constituição Federal, que, por um lado, garante aos executados a ampla defesa, direito à informação e à comunicação e, por outro lado, garante aos exequentes o princípio da celeridade processual, e no caso da venda em público leilão, a Lei processual Civil no inciso II do Artigo 879 garante como legal que "a alienação far-se-á em leilão judicial eletrônico" (BRASIL, 2015), sendo previsto que tal modalidade no $\S 3^{\circ}$ do Artigo 880 do Código de Processo Civil quando "tribunais editar disposições complementares sobre o procedimento da alienação, admitindo, quando for o caso, o concurso de meios eletrônicos" para que o leiloeiro efetivamente realize o leilão na modalidade eletrônica (BRASIL, 2015).

Para a realização do Leilão eletrônico, é mister a análise um importante aspecto fundamental também previsto no $\$ 3^{\circ}$ do Artigo 880 do Código de Processo Civil que o Leiloeiro esteja no regular "exercício profissional por não menos que 3 (três) anos" (BRASIL, 2015) e possua sistema informatizado para controle dos bens removidos, com fotos e especificações, para consulta on-line pelo Tribunal, assim como de que dispõe de equipamentos de gravação do leilão eletrônico. Segundo o $§ 1^{\circ}$ do artigo 882 do Código de Processo Civil “a alienação judicial por meio eletrônico será realizada, observando-se as garantias processuais das partes, de acordo com regulamentação específica do Conselho Nacional de Justiça" bem como no seu $\S 2^{\circ}$ do mesmo artigo que "a alienação judicial por meio eletrônico deverá atender aos requisitos de ampla publicidade, autenticidade e segurança, com observância das regras estabelecidas na legislação sobre certificação digital" 
(BRASIL, 2015).

Vale ressaltar que muitos Tribunais criaram e estão criando Comissões Provisórias de Credenciamento de leiloeiros para definição e análise do cumprimento das disposições editalícias e normativas, em especial os requisitos tecnológicos (CNJ, 2017).

Nesse aspecto, os avanços da Internet e do mundo digital ocorrido nos últimos anos ocasionaram uma revolução na vida das pessoas, facilitando a divulgação, a segurança e, sobretudo a transparência na venda de bens por ordem do Poder Judiciário.

Importante frisar que outrora era comum notícias de que alguns leilões eram realizados com pouca ou nenhuma divulgação, restringindo, assim, a concorrência. Tais noticiais tem se tornado cada dia menos frequente visto que a circulação de dados propiciadas pela Internet garante que os atos do leiloeiro sejam amplamente divulgado na rede mundial de computadores, dificultando desta forma eventuais direcionamentos quando os bens são ofertados na modalidade eletrônica visto que os dados estão armazenados no sistema do Leiloeiro Público e do Juízo do Tribunal de Justiça que ordenou a venda daqueles bens (KRONBERG, 2018).

Desde modo, o leilão eletrônico além de garantir o princípio da celeridade processual, da ampla defesa e maior arrecadação na oferta pública de lances, permite ainda aos jurisdicionados e a sociedade de uma forma geral que participem dos leilões sem que haja necessidade de que se desloquem presencialmente até o Átrio do Fórum para ofertar um lance diante de um Leiloeiro.

Portanto, nota-se que o leilão judicial eletrônico mostra-se importante exemplo para a proteção de direitos individuais e coletivos das pessoas, sobretudo no bem estar e na saúde dos Brasileiros, sendo importante estratégia para evitar aglomerações sociais e o contágio pelo novo coronavírus. Destaca-se que também constitui um modelo para o sistema econômico Brasileiro e para outras áreas do direito no regular seguimento das ações judiciais sem que ocorra a disseminação do tristemente afamado COVID-19.

\section{REQUISITOS LEGAIS E VANTAGENS DO LEILÃO ELETRÔNICO}

O Leilão Virtual foi normatizado como regra geral para a venda dos bens penhorados tudo conforme disposto no Artigo 882 do CPC, "Não sendo possível a sua realização por meio eletrônico, o leilão será presencial” (BRASIL, 2015), ou seja, sempre que possível a 
venda dos bens penhorados será virtual. Frisa-se que o $\S 1^{\circ}$ do Artigo 882 do CPC afirma que “a alienação judicial por meio eletrônico será realizada, observando-se as garantias processuais das partes, de acordo com regulamentação específica do Conselho Nacional de Justiça” (BRASIL, 2015).

A lei também assegura, no artigo 901 caput e $\$ 1^{\circ}$ e $\$ 2$ do CPC, que comprovado o pagamento eletrônico da guia de depósito judicial ou prestadas as garantias pelo arrematante, bem como realizado o pagamento da comissão do leiloeiro e das demais despesas da arrematação o arrematante tem o direito de receber a ordem de entrega do bem móvel via mandado de imissão na posse e a expedição da Carta de Arrematação para o registro no seu nome (BRASIL, 2015). Ou seja, se a própria lei garante celeridade na entrega do bem arrematado quanto a efetivação do registro da arrematação junto ao competente órgão registral, dispensando-se a necessidade da lavratura de escrituras públicas de compra e venda e a distribuição de ações autônomas para a entrega do bem comprado quiçá quanto ao modus operandi na atuação do leiloeiro no cumprimento do seu múnus público ante a realização da almoeda.

Por tudo isso, nota-se que são muitas as vantagens do leilão eletrônico, e que até hoje se mostra como instituto observador da legislação vigente bem como cumpridor das "garantias processuais das partes, de acordo com regulamentação específica do Conselho Nacional de Justiça" e que estas vantagens devem ser usadas como exemplo para adequação de medidas para outros atos processuais quiçá para a administração pública na adoção de medidas de contenção a disseminação do COVID-19.

Assim, a partir da análise do texto legal e dos atos do CNJ (2016), é possível explicitar dentre inúmeras vantagens dos leilões eletrônicos aquelas que se relacionam claramente com as medidas de isolamento social provocada em decorrência da COVID-19, que abaixo mencionamos:

a) Expedição e publicação dos editais do público leilão eletrônico, dispensando a publicação em classificados pouco acessados daqueles chamados jornais de grande circulação;

b) Democratização e transparência do acesso as oportunidades de compra em leilão eletrônico;

c) Realização por videoconferência dos atos do pregão por parte do leiloeiro público, 
podendo ser acompanhado pelo Juízo, pelas partes, pelos procuradores ou por quaisquer interessados naquele ato;

d) Acesso e análise das fotografias e vídeos dos bens ofertados;

e) Analise virtual de eventuais gravames, arrestos, sequestros, penhoras, hipotecas, débitos propter-rem, etc por advogados, arrematantes e interessados na almoeda.

f) Publicação dos documentos e das certidões dos bens móveis ou imóveis, tais como $\mathrm{O}$ Certificado digital de Registro e Licenciamento de Veículo ( $C R L V)$ que dispõe de todas as informações do documento impresso e a mesma validade jurídica do CLRV na modalidade físico, a certidão enfitêutica, a certidão do Registro de Imóveis, as certidões distribuidoras, etc;

g) Analise virtual das condições de venda, forma de pagamento, eventuais parcelamentos do lance e sanções cíveis e penais em caso de inadimplência no pagamento do lance ora ofertado;

h) Recebimento da guia eletrônica de depósito judicial pelo arrematante do lance vencedor, facultando o pagamento de forma remota pelo sistema bancário após a expedição via convênio com o Banco do Brasil ou a Caixa Econômica Federal;

i) Disputa transparente e democrática de lances com o recebimento de diversos lances antes mesmo da data do leilão, permitindo ainda a contagem de prazo para a realização do leilão em meses, dias, minutos e segundos para a batida do martelo do leiloeiro;

j) Expedição do auto de arrematação com assinatura eletrônica pelo Juízo do processo, pelo leiloeiro que realizou a hasta pública e pelo arrematante que vencer na batida do martelo e finalmente será habilitado nos autos como $3^{\circ}$ interessado, tornando assim o ato perfeito e acabado.

Nesse aspecto, o leilão eletrônico foi muitíssimo favorecido com os avanços da Internet e do mundo digital, facilitando a divulgação, a segurança e sobretudo a transparência na venda de bens por ordem do Poder Judiciário, garantindo aos jurisdicionados e a toda a sociedade, transparência e rapidez no ato da expropriação de bens com maior arrecadação financeira e sobretudo a manutenção do isolamento social pois todo o ato se realizada de forma remota.

\subsection{NORMATIZAÇÕES PELO CONSELHO NACIONAL DE JUSTIÇA (CNJ)}

Rev. Brasileira de Direito Civil em Perspectiva | e-ISSN: 2526-0243 | Evento Virtual | v. 6 | n. 1 |

p. 39-55 | Jan/Jun. 2020 
O CNJ em dezembro de 2015 criou um grupo de trabalho "formado pelos conselheiros Gustavo Alkimin (presidente), Arnaldo Hossepian, Carlos Levenhagen, Carlos Dias, Fernando Mattos e Luiz Allemand" que dentre diversas atividades "iniciou consulta pública sobre os temas do novo CPC entre março e abril de 2016, resultando em 413 manifestações e sugestões”, resultando na versão final da Resolução 236 votada no plenário, garantindo a observância do $\S 2^{0}$ do Artigo 882 do CPC que assegura a alienação judicial por meio eletrônico "deverá atender aos requisitos de ampla publicidade, autenticidade e segurança, com observância das regras estabelecidas na legislação sobre certificação digital", ou seja o Leilão virtual é um mecanismo que somente poderá ser realizado se observado os requisitos mínimos mencionados nos referidos ditames Legais (CNJ, 2016).

Importante salientar que após a nomartização do CNJ para o leilão eletrônico digital, conseguiu-se finalmente unificar a forma de atuação dos leiloeiros em todo o território Nacional, bem como no melhor serviço jurídico para os Advogados e para as partes em um determinado processo, além de garantir ao Juízo o manifesta senso de justiça na atuação do leiloeiro por Ele nomeado, cujo atuação é configurada segundo Dinamarco (2016, p. 994-995) como:

um auxiliar da justiça ainda que atue apenas eventualmente nos processos judiciais - configurando-se um auxiliar eventual da justiça ao desempenhar a função de conduzir um procedimento para a venda de bem penhorado, fá-lo em sede processual, complementando a atividade jurisdicional de prestar tutela ao direito e sob a autoridade do juiz.

Nota-se que em dias de pandemia que o Leilão eletrônico traz importantes reflexões jurídicas em resposta ao isolamento social neste período de COVID-19, mostrando-se claramente um importante aliado na preservação de vidas.

Quando a alienação judicial, por meio eletrônico, foi regulamentada observou-se as garantias processuais das partes, assegurando ainda requisitos mínimos para o credenciamento de leiloeiros e procedimentos para sua nomeação (CNJ, 2016).

Assim, é importante frisar que a atuação do leiloeiro como auxiliar do Juízo ganhou bastante relevância jurídica e social para a sociedade e para outras áreas do direito quando realizado na modalidade virtual. 


\subsubsection{LEILOEIRO PÚBLICO OFICIAL: UMA PROFISSÃO ESTRATÉGICA}

Na atualidade ainda é a Lei Federal 21.981 de 19 de outubro de 1932 que regulamenta a profissão de Leiloeiro em todo o território nacional e que disciplina e normatiza as atividades exercidas pelos Leiloeiros.

Para o regular exercício da Profissão se faz necessário análise do Art. $2^{\circ}$ da Lei Federal 21.981 de 19 de outubro de 1932 que assegura que para ser leiloeiro, é necessário provar:

a) ser cidadão brasileiro e estar no gozo dos direitos civis e políticos;

b) ser maior de vinte e cinco anos;

c) ser domiciliado no lugar em que pretenda exercer a profissão, há mais de cinco

d) ter idoneidade, comprovada com apresentação de caderneta de identidade e de certidões negativas dos distribuidores, no Distrito Federal, da Justiça Federal e das Varas Criminais da Justiça local, ou de folhas corridas, passadas pelos cartórios dessas mesmas Justiças, e, nos Estados e no Território do Acre, pelos Cartórios da Justiça Federal e Local do distrito em que o candidato tiver o seu domicílio.

Além das determinações acima mencionadas, o caput do Art. $6^{\circ}$ da referida Lei ainda dispõe como condição sine qua non que "cada leiloeiro é abrigado, após a habilitação, perante às Juntas comerciais e mediante despacho destas, a prestar a fiança de 40:000\$0, em dinheiro ou apólices da dívida pública federal, que será recolhida, no Distrito Federal, ao Tesouro Nacional e, nos Estados e no Território do Acre, às Delegacias Fiscais, Alfândegas ou Coletorias Federais" (BRASIL, 1932).

Dispõe ainda como condicional para o cargo de Leiloeiro os parágrafos $1^{\circ}$ ao $3^{\circ}$ que:

"§ $1^{\mathrm{o}}$ A fiança em apólices nominativas será prestada com o relacionamento desses títulos na Caixa de Amortização, ou nas repartições federais competentes para recebê-la, dos Estados e no Território do Acre, mediante averbações que as conservem intransferíveis, até que possam ser levantadas legalmente, cabendo aos seus proprietários a percepção dos respectivos juros".

"§ $2^{\circ}$ Quando se oferecem como fiança depósitos feitos nas Caixas Econômicas, serão as respectivas cadernetas caucionadas na forma do parágrafo anterior, percebendo igualmente os seus proprietários os juros nos limites arbitrados por aqueles institutos."

"§ $3^{\circ}$ A caução da fiança em qualquer das espécies admitidas, a, bem

Rev. Brasileira de Direito Civil em Perspectiva | e-ISSN: 2526-0243 | Evento Virtual | v. 6 | n. 1 | 
assim o seu levantamento, serão efetuados sempre à requisição da Junta Comercial perante a qual se tiver processado a habilitação do leiloeiro".

O Art. $7^{\circ}$ da Lei Federal 21.981 de 19 de outubro de 1932 assegura que existem algumas garantias condicionais para o deferimento da matrícula do Leiloeiro Público e que tais garantias devem ser observadas no momento do requerimento da autorização para o exercício da atividade, seja garantia de idoneidade, financeira, bons antecedentes, não ser empresário, dentre outras.

A fiança que o candidato à função de Leiloeiro presta responde pelas dívidas ou responsabilidades do leiloeiro, originadas por multas, infrações de disposições fiscais, impostos federais e estaduais relativos à profissão, saldos e produtos de leilões ou sinais que ele tenha recebido e pelas vendas efetuadas de bens de qualquer natureza, e subsistirá até 120 dias, após haver deixado o exercício da profissão, por exoneração voluntária, destituição ou falecimento.

Para ser Leiloeiro deve o candidato, "apresentar também certidão negativa de ações ou execuções movidas contra ele no foro civil federal e local, correspondente ao seu domicílio e relativo ao último quinquênio" (BRASIL, 1932; JUNTA COMERCIAL/RJ, 2015).

A referida Lei 21.981/1932 assegura ainda ao postulante da função de Leiloeiro Público que para o exercício da atividade, o Cidadão não fará concurso público, mas, prova de títulos, certidões dos distribuidores negativas e depósito de garantia financeira no valor atual de $\mathrm{R} \$ 40.000,00$ (quarenta mil reais) a título de caução junto à Caixa Econômica Federal que ficará retida para garantia de eventuais irregularidades quanto a prestação do serviço junto aos jurisdicionados e a sociedade de uma forma geral, tudo conforme deliberação $n^{\circ} 83$, de 24 de junho de 2015 da Junta Comercial do Estado do Rio de Janeiro, tomada aqui como exemplo.

Vale mencionar que a referida deliberação permitiu ainda aos Leiloeiros que a garantia também poderá ser prestada através de fiança bancária ou seguro garantia, que deverão ser contratados junto a instituições financeiras ou seguradoras privadas, devendo, em qualquer hipótese, constar da apólice cobertura de, no mínimo, $\mathrm{R} \$ 40.000,00$ (quarenta mil reais), cuja vigência deverá abranger o período de 1 (um) ano, facultado ao interessado oferecer garantia para períodos superiores.

Diante desses pré requisitos, não é possível que o Estado remunere a atividade dos Leiloeiros, pois se trata de atividade autônoma em colaboração com o Estado perante o Poder Judiciário denominado "Auxiliar do Juízo". Praticamente o mesmo entendimento tem Maria 
Sylvia Zanella Di Pietro (2015), para quem os particulares em colaboração com o Estado, desempenham serviços sem vínculo empregatício, com ou sem remuneração paga pelo poder público e sob diversos títulos. Eles compreendem: a) os delegatários de serviços públicos; os delegatários de serviços notariais e de registro (art. 236 da Constituição); os leiloeiros, tradutores, intérpretes, que exercem função pública em seu próprio nome, porém com fiscalização dos órgãos públicos. A remuneração que todos eles recebem não é paga pelos cofres públicos, mas por usuários do serviço e no caso do leiloeiro a sua remuneração é previamente fixada pelo Juiz do processo e paga pelo Arrematante que comprou um bem no leilão ocorrendo ainda hipóteses que o réu/executado seja obrigado a pagar uma verba de honorários com o leiloeiro como forma de remunerar os serviços por ele desenvolvidos.

Como a atividade de Leiloeiro foi planejada para ser aquela que "busca constantemente a superação dos lances sob as regras previstas no regime jurídico legal”, deve então a atividade ser remunerada. Como visto, a Lei 21.981/1932 prevê que os Leiloeiros não farão concurso público para o exercício de seu mister mas, prova de títulos, formação secundária e depósito de garantia financeira caução na Caixa Econômica Federal. Diante desses pré-requisitos, não é possível que o Estado remunere a atividade dos Leiloeiros, pois se trata de atividade autônoma em colaboração com o Estado também conhecido perante o Poder Judiciário como Auxiliar do Juízo.

Os particulares em colaboração com o Estado, desempenham serviços sem vínculo empregatício, com ou sem remuneração paga pelo poder público e sob diversos títulos. Eles compreendem: a) os delegatários de serviços públicos; os delegatários de serviços notariais e de registro (art. 236 da Constituição da Republica Federativa do Brasil); os leiloeiros, tradutores, intérpretes, que exercem função pública em seu próprio nome, porém com fiscalização dos órgãos públicos (DI PIETRO; MOTA FERRAZ, 2015; BRASIL, 1988).

A remuneração que todos eles recebem não é paga pelos cofres públicos, mas por usuários do serviço. b) os requisitados, nomeados ou designados para o exercício de função pública relevante, tal como os jurados, os convocados para serviço militar ou eleitoral, os comissários de menores, os integrantes de comissões e grupos de trabalho. Estes também não possuem vínculo empregatício e, em geral, não recebem remuneração. c) os gestores de negócio, que espontaneamente e em momento de emergência assumem alguma função pública, tal como em caso de epidemia, incêndio, enchente e outras calamidades (DI PIETRO; MOTA FERRAZ, 2015, p.2). 
Os Leiloeiros encontram-se contemplados na Lei Federal 21.981/1932 que regula a profissão de Leiloeiro no território da República Federativa do Brasil e, será "exercida mediante matricula" após o "depósito de caução concedida pelas juntas Comerciais", logo não será considerado Funcionário Público (BRASIL, 1932).

Dessa forma, pode se dizer que compete aos leiloeiros, pessoal e privativamente, a venda em hasta pública ou público pregão, dentro de suas próprias casas ou fora delas, inclusive por meio da rede mundial de computadores, de tudo que, por autorização de seus donos por alvará judicial, forem encarregados, tais como imóveis, móveis, mercadorias, utensílios, semoventes e mais efeitos, e a de bens móveis e imóveis pertencentes às massas falidas, liquidações judiciais, penhores de qualquer natureza, inclusive de joias e warrants de armazéns gerais, e o mais que a lei mande, com fé de oficiais públicos, permitindo assim ao Leiloeiro receber do arrematante a comissão estabelecida em lei ou arbitrada pelo juiz (DI PIETRO; MOTA FERRAZ, 2015).

Quem paga a comissão do Leiloeiro é o Arrematante, ou seja, aquele que arremata o bem após a disputa dos lances no Leilão, tudo conforme disposto no Parágrafo único do Artigo 884 CPC que assegura que "o leiloeiro tem o direito de receber do arrematante a comissão estabelecida em lei ou arbitrada pelo juiz" (BRASIL, 1932).

A comissão é paga quando o Leiloeiro finaliza o Leilão e lavra o auto de arrematação, conforme disposto no Art. 901 do Código de Processo Civil, que prevê "arrematação constará de auto que será lavrado de imediato e poderá abranger bens penhorados em mais de uma execução, nele mencionadas as condições nas quais foi alienado o bem" (BRASIL, 1932).

O pagamento que o Arrematante faz ao Leiloeiro é realizado no ato da "batida do martelo", pois, os incisos I ao V e o $§$ único do Artigo 884 do CPC determinam que:

Incube ao Leiloeiro Público publicar o edital, anunciando a alienação; realizar o leilão onde se encontrem os bens ou no lugar designado pelo juiz; expor aos pretendentes os bens ou as amostras das mercadorias; receber e depositar, dentro de 1 (um) dia, à ordem do juiz, o produto da alienação; prestar contas nos 2 (dois) dias subsequentes ao depósito.

Caso o Arrematante não pague a comissão do Leiloeiro bem como o lance ofertado, o $\S 5^{\circ}$ do Artigo 895 do CPC determina que:

A ordem de entrega do bem móvel ou a carta de arrematação do bem imóvel, com o respectivo mandado de imissão na posse, será expedida 
depois de efetuado o depósito ou prestadas as garantias pelo arrematante, bem como realizado o pagamento da comissão do leiloeiro e das demais despesas da execução.

Vale ressaltar que caso ocorra inadimplência do Arrematante nos pagamentos com a arrematação e com o Leiloeiro, o $§ 1^{\circ}$ do Artigo 901 do CPC assegura ainda que:

o inadimplemento autoriza o exequente a pedir a resolução da arrematação ou promover, em face do arrematante, a execução do valor devido, devendo ambos os pedidos ser formulados nos autos da execução em que se deu a arrematação.

Ante o exposto, pode-se perceber que a função do leiloeiro é central na organização dos processos do leilão, sobretudo, no leilão eletrônico. A função é regulamentada e garantida sua remuneração de forma a não onerar ao estado e ainda sim promover formas de assistência à justiça. Presume-se que a figura do leiloeiro, em âmbito digital, em tempos de pandemia e isolamento ganhará notoriedade e visibilidade social, promovendo-se uma maior acessibilidade e continuidade dos serviços em favor de inúmeros jurisdicionados.

\section{O LEILÃO ELETRÔNICO: REFLEXÕES JURÍDICAS EM RESPOSTA AO ISOLAMENTO SOCIAL}

O Leilão Eletrônico foi normatizado como regra geral para a venda dos bens penhorados e tornou-se a primeira opção na venda dos bens penhorados será na modalidade virtual. Verifica-se que leilão é um contrato de venda e segundo Miranda (1974, p. 270-271):
negar-se que seja contrato a hasta pública, com a arrematação, a adjudicação, ou a remição, não é negar-lhe a negocialidade, nem, sequer, a bilateralidade negocial; é apenas negar-lhe a contratualidade. Quando algum jurista investe, armas em riste, contra a afirmação de ser negocial a arrematação, ataca o quartel vizinho àquele que tinha de atacar, aquele que pertence aos contratos.

Nota-se que além das vantagens explicitadas no item 03 deste trabalho que com a modalidade de leilão virtual outra vantagem em dias de COVID-19 se mostra de relevada importância que é o de evitar tumultos e aglomeração de pessoas que habitualmente ocorria no Átrio do Fórum ou no auditório disponível pelo Poder Judiciário. O Leilão eletrônico também viabiliza a participação de uma quantidade maior de pessoas interessados nos bens e 
reduz a ocorrência de desistências de arrematantes em meio as comuns aglomerações ocasionadas pelos leilões tradicionais.

Importante destacar que início das vendas pelo leilão eletrônico foi difícil a adaptação do presencial para o digital, e, assim, era comum realizar a venda na modalidade hibrida (presencial e eletrônica), entretanto com a ampliação do processo eletrônico e da facilidade em adquirir os certificados digitais, tornou-se ampliado o alcance dos leilões judiciais eletrônicos. Desta forma, se faz mister realçar que as inúmeras medidas de prevenção da disseminação do COVID-19 podem seguir o exemplo do leilão eletrônico que em suma já se mostrava um aliado em evitar o contágio do COVID-19 e na atual aplicação de restrição de pessoas ao acesso ao prédio do Poder Judiciário visto que desenvolvido totalmente de forma remota.

Em suma, percebesse perfeitamente que aquilo que já se realizava no leilão eletrônico com os impactos da inclusão do leilão eletrônico na legislação brasileira (desde 2015) foi bastante positiva e sem dúvidas deve ser seguido como exemplo pela Administração Pública e diversos outros setores da Sociedade pois mostra-se eficaz no cumprimento da ordem judicial, no atendimento das partes do processo bem como aos terceiros interessados, seja na divulgação dos leiloes, na oferta dos lances e sobretudo na proteção e preservação da saúde e vida dos indivíduos.

\section{CONSIDERAÇÕES FINAIS}

Como visto, a realização de leilão virtual foi normatizada pelo Conselho Nacional de Justiça cuja armazenagem de dados ficará a cargo do Leiloeiro devidamente matriculado na Junta Comercial e cadastrado perante a Corregedoria Geral de Justiça do Estado que foi matriculado, fazendo com que os conteúdos da internet possam ser mantidos e disponibilizados na rede permitindo a utilização por qualquer pessoa, a qualquer tempo. Dessa forma entende-se que no curso desta pandemia será necessária a manifestação de instituições publicas na instância dos três poderes para validar projetos de inovação e tecnologia a serviço do direito e da população.

O CPC regulamenta o âmbito presencial e virtual, inclusive, dispões sobre a atuação do Leiloeiro, estipulando os direitos e deveres dos Leiloeiros, Arrematantes, Credores e Devedores, além dos usuários das plataformas eletrônicas de Leilão, disciplinando as relações 
estabelecidas na Internet e também possui como norte os direitos econômicos. Assegura que seriam os atos normatizados pelo Conselho Nacional de Justiça e estes por sua vez condicionaram as Corregedorias de Justiça do Estado onde o Leiloeiro possui matricula a regulamentação de Leilão eletrônico bem como o cadastramento dos Leiloeiros que serão responsabilizados por conteúdo postado na plataforma, pela publicação dos editais dos Leilões, dos anúncios e, sobretudo no recebimento do maior número de lances e, ao ser solicitado judicialmente que colabore para maior celeridade possível nos atos da expropriação judicial.

Vale ressaltar que Leilão eletrônico é uma modalidade ágil, transparente e que possibilita uma disputa equilibrada de lances entre os arrematantes. Além disso, tornou efetivamente mais eficiente e barato o processo da expropriação judicial, por permitir a simplificação de muitas das etapas burocráticas que tornavam morosa a realização da almoeda Tomando por exemplo a praxe do leilão eletrônico, notamos que a atuação dos leiloeiros tem resultado em maior transparência na venda pública de bens penhorados garantindo assim acesso a todos quantos queriam participar e lançar naquele público leilão, permitindo maior alcance no recebimento dos lances e consequentemente maior arrecadação para os autos do processo ao permitir que uma infinidade de interessadas no leilão participem sem que haja necessidade da deslocação desses interessados até o Átrio do Fórum como era praxe antes do CPC de 2015.

Além disso, vale informar que para um arrematante participar de um leilão eletrônico deverá este interessado previamente se cadastrar no sistema de Leilões Virtuais, tendo como condição mínima apresentar seus documentos pessoais e assinar virtualmente termo de responsabilidade assegurando o devido cumprimento com as regras impostas no Edital do Leilão e na lei vigente, garantindo desta forma maior efetividade no pagamento dos lances e no recebimento dos honorários do Leiloeiro e maior transparência e seriedade no ato da expropriação judicial, evitando-se eventuais desvios de conduta por quem quer que seja.

O instituto jurídico do leilão se destacada como um dos pioneiros a se adequar à era digital, sendo possível utilizá-lo, frisa-se, como referência para outras situações de adaptação de serviços e prestações jurisdicionais durante a pandemia gerada pelo COVID-19, sendo, portanto, exemplo a ser seguido com objetivo final de se evitar possíveis danos ao erário público e a saúde de todas as pessoas em sociedade.

Podemos concluir que o leilão eletrônico além de facilitar o alcance de um número 
maior de interessados e possíveis arrematantes na arrematação de um determinado bem, facilitado pela divulgação virtual e pela amplitude negocial relacionados ao e-Business que é o seu principal objetivo, garante ainda a segurança jurídica e a regular observância do princípio da dignidade da pessoa humana como fundamento jurídico dos direitos fundamentais ao preservar a saúde e a vida das pessoas, podendo ser um exemplo contributivo para outras áreas do Direito em tempos de isolamento social provocado pela pandemia do COVD-19.

\section{REFERÊNCIAS}

BRASIL. Conselho Nacional de Justiça (CNJ). Atos normativos. 2017. Disponível em: <http://www.cnj.jus.br///images/atos_normativos/resolucao/resolucao_236_13072016_15072 016155240.pdf $>$. Acesso em 30 de abril de 2020.

.Conselho Nacional de Justiça (CNJ). Conselho regulamenta a alienação judicial eletrônica. https://cnj.jusbrasil.com.br/noticias/361919856/conselho-regulamenta-alienacaojudicial-eletronica-conforme-novo-cpc. 2016. Acesso em 30 de abril de 2020.

. Conselho Nacional de Justiça (CNJ). Resolução do Conselho Nacional de Justiça 236, de 13 de julho 2016.

Constituição (1988). Constituição da República Federativa do Brasil. Brasília, DF: Senado Federal: Centro Gráfico, 1988. 292p

Decreto ${ }^{\circ} 21.981$ de 19 de outubro de 1932. Regula a profissão de Leiloeiro ao território da República. 1932. Disponível em:

http://www.planalto.gov.br/ccivil_03/decreto/1930-1949/D21981.htm. Acesso em 30 de abril de 2020.

. Lei n ${ }^{\circ} 13.105$, de 16 de março de 2015. Código de Processo Civil. Diário Oficial da União, Brasília, 2015b. Disponível em: http://www.planalto.gov.br/ccivil_03/_ato20152018/2015/lei/113105.htm. Acesso em: 30 de abril de 2020.

DINAMARCO, Cândido Rangel. Instituições de Direito Processual Civil. 8. ed. São Paulo: Malheiros, IV. 2016. p. 852. Igualmente: ASSIS, Araken de. Processo civil brasileiro. São Paulo: Ed. RT, 2015. v. II. t. I. p. 994-995.

DI PIETRO, Maria Sylvia Zanella; MOTTA, Fabrício; FERRAZ, Luciano de Araújo. Servidores públicos. Servidores públicos na Constituição de 1988. Atlas. 2015. p. 2.

JUNTA COMERCIAL - RJ. Deliberação n83, de 24 de junho de 2015. Ato Normativo. Rio de Janeiro. 2015. Disponível em: https://www.jucerja.rj.gov.br/Legislacao/Deliberacoes. Acesso em: 30 de abril de 2020. 
KRONBERG, Helcio. Leilões Judiciais e Extrajudiciais. 2018. Editora Hermus. Ed.2. São Paulo. ISBN-13:9788528906262.

MIRANDA, Francisco Cavalcanti Pontes de. Comentários ao Código de Processo Civil. 2. ed. t. 10. 1974, p. 270-271.

RODRIGUES, Sônia Maria de Menezes. Leiloeiro oficial - Junta comercial -

Poderes. Revista de Direito Administrativo, Rio de Janeiro, v. 221, p. 337-342, jul. 2000. ISSN 2238-5177. Disponível em:

<http://bibliotecadigital.fgv.br/ojs/index.php/rda/article/view/47603/45126>. Acesso em: 30 de abril de 2020. doi:http://dx.doi.org/10.12660/rda.v221.2000.47603.

WORLD HEALTHORGANIZATION (WHO). Painel de situação do COVID-19. 2020.

Disponível em: https://www.who.int/es/emergencies/diseases/novel-coronavirus-201. Acesso em 30 de abril de 2020. 